\title{
NEAR-DROWNING: AN UNUSUAL CASE
}

\author{
J.E. MONTES AND A.W. CONN
}

\begin{abstract}
This paper reports the case of a 2 year-old male who appeared to have drowned in the family swimming pool. Immediate continuous cardiopulmonary resuscitation eventually restored circulation and respiration. Subsequently, in the intensive care unit, he appeared to "cone" and suffer brain "death". Prompt and continuous use of measures to support cerebral resuscitation were successful and the child subsequently was completely normal. A reevaluation of current information seems indicated in regard to the prognosis of the neardrowned child.
\end{abstract}

IN DROWNING ACCIDENTS, an infant or child may appear to be irreversibly "dead" at the time of rescue. Nevertheless, the immediate commencement and maintenance of cardiopulmonary resuscitation (CPR) for prolonged periods (1-2 hours $)^{1,2}$ can lead to successful restoration of circulation and ventilation, especially if associated with immersion hypothermia. ${ }^{3-6}$ If, in addition, specific measures for cerebral "salvage" are subsequently carried out,,10 a significant proportion of these victims can achieve complete recovery. ${ }^{8,1}$ Increasing public knowledge of resuscitation techniques has resulted in the arrival at hospital of patients with evidence of major brain damage after severe asphyxia. The necessity of continuing full treatment for at least 24 hours following hospital admission is suggested by the following case.

\section{CASE REPORT}

On July 6, 1979 at 1330 hours, a $2 \frac{1}{2}$-year-old male (A.A.), was found by his mother at the bottom of the family swimming pool following estimated submersion of five minutes. Recovery was difficult and complicated by mild head trauma. Cardiopulmonary resuscitation was started at the scene by a neighbour and maintained for approximately 30 minutes by paramedical personnel en route to the local hospital.

On arrival, at 1350 hours, his pupils were fixed and dilated, with absent pulse and blood pressure and respiratory arrest. His trachea was intubated and he was ventilated with 100 per cent oxygen while intracardiac adrenaline and calcium chloride were administered and sodium bicarbonate was given intravenously. Ventricular fibril-

J.E. Montes, M.B., Fellow, Intensive Care Unit; A.W. Conn, M.D. F.R.C.P.(C), Director, Intensive Care Unit, Hospital for Sick Children, 555 University Avenue, Toronto, Ontario M5G 1 X8.

Canad. Anaesth. Soc. I., vol. 27, no. 2, March 1980 lation was noted on the electrocardiogram and successful cardioversion was carried out. His rectal temperature was less than $35^{\circ} \mathrm{C}$ and initial blood gas determinations revealed $\mathrm{cH}^{+} 104.7$ $\mathrm{nmol} / \mathrm{l}$ ( $\mathrm{pH} 6.98$ ) with a base excess of $-25 \mathrm{~m}$ $\mathrm{mol} / \mathrm{l}$.

Approximately 45 to 50 minutes after rescue ( 1420 hours) his heart rate was 160 per minute and blood pressure $90 / 60$ torr, but pupillary reactions were very sluggish. He was unresponsive to pain, but was shivering, had "gaspy" respiration and decerebrate posturing. Following consultation, specific therapy for cerebral resuscitation was

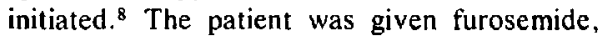
dexamethasone, pancuronium bromide, mannitol and phenobarbitone intravenously. Intravenous fluid was severely restricted and manual hyperventilation with oxygen was continued during transfer to The Hospital for Sick Children, Toronto.

On admission to the intensive care unit ( 1600 hours) the patient was comatose with "decorticate" posturing, but sluggish symmetrical pupillary responses were present. He was shivering (temperature $35.5^{\circ} \mathrm{C}$ ) with "gaspy" respirations. Systolic blood pressure was $14.63 \mathrm{kPa}$ (110 torr) and pulse rate was 100 per minute. Within 10 minutes of arrival, his blood pressure had risen to $23.94 \mathrm{kPa}$ (180 torr), pulse rate was $80 / \mathrm{min}$, the pupils became fixed and dilated with absent venous pulsations on fundoscopic examination. He was then hyperventilated vigorously with 100 per cent oxygen, given additional pancuronium, furosomide, mannitol, thiopentone and phenobarbitone. There was no clinical response to this therapy. An immediate electroencephalogram was "flat" in all leads and neurosurgical evaluation at the time strongly suggested acute cerebral herniation with brain death. In all "comatose cases" of near-drowning, con- 
tinuous monitoring of intracranial pressure is mandatory, but was omitted in this case for obvious reasons.

Despite this situation, cerebral resuscitation, as previously published ${ }^{8}$ (H.Y.P.E.R. protocol) was continued and maintained for $3 \frac{1}{2}$ days, as follows:

1. His intravenous fluid was restricted to $\mathbf{3 0}$ per cent of normal maintenance. Central venous pressure was maintained at 0.4 to $1.06 \mathrm{kPa}$ (3-8 torr) and urine output between $0.5-0.75$ $\mathrm{ml} \cdot \mathrm{kg}^{-1} /$ hour. Daily cardiac output determinations were done but no inotropic agents or volume expanders were needed.

2. Controlled hyperventilation to maintain his $\mathrm{Pa}_{\mathrm{CO}_{2}}$ at $4.0 \pm 0.4 \mathrm{kPa}(30 \pm 3$ torr $)$ and his $\mathrm{Pa}_{\mathrm{O}_{2}}$ was maintained at $19.95 \pm 2.66 \mathrm{kPa}(150 \pm 20$ torr) with high oxygen concentrations and up to $10 \mathrm{~cm} \mathrm{H} \mathrm{H}_{2} \mathrm{O}$ PEEP.

3. Hypothermia was maintained $30 \pm 1^{\circ} \mathrm{C}$.

4. Barbiturate coma was maintained using phenobarbitone with a loading dose of 50 $\mathrm{mg} \cdot \mathbf{k g}^{-1}$ intravenously and daily maintenance doses of $30 \mathrm{mg} \cdot \mathrm{kg}^{-1}$ intravenously to obtain satisfactory blood levels between 70 and 120 $\mathrm{mg} / \mathrm{litre}$.

5. Total muscular paralysis was maintained using pancuronium bromide.

In addition, dexamethsaone was administered (loading dose $0.2 \mathrm{mg} \cdot \mathrm{kg}^{-1}$ with $0.1 \mathrm{mg} \cdot \mathrm{kg}^{-1}$ every six hours), despite a lack of conclusive proof to support its use in patients with hypoxic brain insult. Serial cultures were taken from intravascular catheters, blood, tracheal tube and urinary catheter. White cell and platelet count, prothrombin time and plasma thromboplastin time were monitored daily to detect possible sepsis. Numerous other tests and procedures were carried out, but are omitted in this report.

At approximately 1930 hours (six hours postsubmersion) it was noted that his pupils had become smaller and reactive and venous pulsations had reappeared! At 2350 hours, a temporary portable three-lead electroencephalogram monitor was attached and "organized" cerebral activity was demonstrated. The following morning, at 10.00 hours, a second electroencephalographic examination showed remarkable improvement in all leads. Intracranial pressure monitoring using a Richmond Bolt was then instituted immediately.

Subsequently, "cerebral salvage" measures were continued, as outlined previously, for a total of 88 hours without other complications. At that time, relaxants and barbiturates were discon- tinued and the patient was allowed to slowly rewarm and recover. He partially regained consciousness in 100 hours from the start of therapy and was fully conscious 72 hours later. He was discharged from the hospital 17 days after admission. Subsequent follow-up visits to neurology and child development clinics have confirmed a complete neurological recovery.

\section{Discussion}

Several points are suggested by this paediatric near-drowning 9 case (as well as others in our series): (a) that immediate diagnosis of cerebral death after drowning cannot be made with accuracy, either at the scene or in the early postsubmersion period. Therefore, immediate resus. citation should be initiated and maintained continuously, regardless of appearances, to allow continuous observation and monitoring for at least 24 hours. (b) After $\mathbf{2 4}$ hours of treatment, if cerebral recovery is progressing satisfactorily, pupillary size and reactions are restored, raised intracranial pressure is readily controllable, and the electroencephalogram, even if originally "flat", will return towards normal despite hyperventilation, hypothermia $\left(30^{\circ} \mathrm{C}\right)$ and very high blood phenobarbitone levels (>150 mg/litre. (c) If there is no clinical improvement during this $24-48$ hour period, it is likely that brain death or major damage has occurred. However, the possibility arises that in a damaged swollen brain, the use of H.Y.P.E.R. therapy could cause a transient rise in intracranial pressure which must be distinguished promptly from either cerebral haemorrhage from trauma or loss of autoregulation from brain "death". If doubt exists, a computerized axial tomography scan is essential to aid in the differential diagnosis.

In conclusion, the widespread use of cardiopulmonary resuscitation combined with numerous measures to support cerebral resuscitation require a re-evaluation of current information involving the prognosis of the near-drowned child. In our experience with 95 cases of neardrowning, this patient's course is rare but not entirely unique.

We thank Dr. Robin Humphreys and our Intensive Care Unit colleagues for their continuous co-operation and support.

\section{REFERENCES}

1. Pickering, B.G., Bristow, G.K. \& Crajg, D.A. Core re-warming by peritoneal irrigation in accidental hypothermia with cardiac arrest: Anaes. Analg. 56: 574-577 (1977). 
2. Bristow, G., SMTth, R., LeE, J., AUty, A. \& TWEeD, W.A. Resuscitation from cardiopulmonary arrest during accidental hypothermia due to exhaustion and exposure. Can. Med. Assoc. J. 117: 247-249 (1977).

3. Stebke. H., Rod, T., Breivik, H. . et al. Survival after 40 minutes submersion without cerebral sequelae. Lancet /: 1275-1277 (1975)

4. Dominguez de Villota, E., Barat, G., Peral, P., et al. Recovery from profound hypothermia with cardiac arrest after immersion. Brit. Med. J. 4: 394 (1973).

5. CONN, A.W. The role of hypothermia in neardrowning. Proceedings of cold water symposium, Royal Life Saving Society of Canada, pp. 33-35 (1976)

6. MODELl. J.H, Drowning and near-drowning Springfield, Illinois, Charles C. Thomas, p. 70 (1971)
7. CONN, A.W., Edmonds, J.F. \& Barker, G.A. Near-drowning in cold fresh water - current treatment regimen. Canad. Anaesth. Soc. J. 25: 259 (1978).

8. Conn. A.W., Edmonds. J.F. \& Barker. G.A. Cerebral resuscitation in near-drowning. Paediatric Clinics of North America 26: 691-701 (1979).

9. SChuman, S.H., Rowe, J.R., Glazier, H.M. et al. The iceberg phenomenon of near-drowning. Soc. Crit. Care Med. 4: 127 (1976).

10. SPENCE, M. Severe intracranial infections. International Anesthesiology Clinics. Vol. 17, pp. 285-306. Buston, Little Brown \& Co. (1979).

11. Trubuhovich. R.V. Water inhalation accidents. New Zealand Jour. Sports Med., 5: Supplement $\# 1,48-54$ ( (1976).

\section{RÉSUMÉ}

Nous présentons un cas d'un māle, agé de $2 \frac{1}{2}$ ans, qui paraissait s“ètre noyé dans sa piscine familiale. La réanimation cardio-pulmonaire continue qui lui a été administrée sur le coup a finalement rendu sa circulation et sa respiration. Plus tard, dans l'unité dessoins intensifs, il paraissait avoir souffert une mort cérébrale. L'emploi rapide el continu de plusieurs mesures pour soutenir la réanimation cérëbrale de l'enfant a remporté du succès et jl était par la suite complétement normal. Il faut évaluer encore l'information courante au sujet du pronostic de l'enfant presque-noyé. 